\title{
A Case Study of Forest and Woodland Habitat Loss to Disturbance and Development in an Ex-Urban Landscape: Santa Clara County, California 1999-2009
}

\author{
Christopher Potter \\ NASA Ames Research Center, Moffett Field, CA, USA \\ Email: chris.potter@nasa.gov
}

Received 7 January 2015; accepted 19 January 2015; published 10 March 2015

Copyright (C) 2015 by author and Scientific Research Publishing Inc. This work is licensed under the Creative Commons Attribution International License (CC BY). http://creativecommons.org/licenses/by/4.0/

\section{(c) (i) Open Access}

\begin{abstract}
Analysis of Landsat satellite images was applied to detect changes in forest and woodland vegetation cover in Santa Clara County, California. Results showed that $92 \mathrm{~km}^{2}(22,730$ acres) of forests and woodlands were highly disturbed in SCC between 1999 and $2009,37 \%\left(34 \mathrm{~km}^{2}\right)$ of which did not overlap with any known wildland fire boundaries, and hence, were confirmed to be lost to new residential or commercial development activities. Disturbed wooded area represented about $6 \%$ of the total $1575 \mathrm{~km}^{2}$ area of all remaining forest and woodlands in SCC prior to 1999. If the majority of disturbed forest and woodland area in SCC is not allowed to regenerate naturally and remain undeveloped, then the annual rate of disturbance would be equal to annual forest loss rates of countries such as Brazil, Venezuela, Mexico, and Madagascar since the year 2000. Based on this assessment, the Landsat analysis methodology would be capable of fulfilling a pressing need for consistent, continual, low-cost monitoring of changes in forest habitats and associated wildlife corridors throughout California.
\end{abstract}

\section{Keywords}

Forest Loss, Land Use Change, Landsat, California, Urban, Development

\section{Introduction}

With an area of $3400 \mathrm{~km}^{2}$ (1315 square miles), Santa Clara County (SCC) California is the second largest county in the nine-county San Francisco Bay Area (SFBA). The Santa Clara Valley is bordered to the east by the 
uplands of the Diablo Mountain Range, to the west by the Santa Cruz Mountains, and to the northwest by the SF Baylands. The Diablo Range consists mainly of grazed grasslands and oak savannah. The Santa Cruz Mountains are covered by grasslands and oak foothills, along with evergreen conifer forests (Forero et al., 1992).

Santa Clara County has seen exponential growth and development during the past several decades. These changes have transformed orchards, farmland, and surrounding woodlands into large tracts of developed commercial and residential space. As a metric of change, the current coverage of fruit and nut trees in SCC stands at less than two percent of the roughly $405 \mathrm{~km}^{2}$ (100,000 acres) at the start of World War II (Diekmann et al., 2013). In the 1950s, population growth rates of more than 50 percent drove the demand for housing and commercial services, resulting in conversion of the Valley's agricultural land into residential subdivisions. By 1975, fruit and nut tree coverage had declined to less than $80 \mathrm{~km}^{2}$ (20,000 acres), and by 1990 to less than $20 \mathrm{~km}^{2}$ (5000 acres). In 2009, there were only about $6 \mathrm{~km}^{2}$ (1500 acres) of fruit and nut trees remaining county-wide (SCCDA, 2009).

Over the past two decades, the Santa Clara Valley has been transformed into "Silicon Valley", a major global center of high-tech development and the Internet boom of the 1990s. San Jose is the largest city within Silicon Valley, and the tenth largest in the United States (“American FactFinder”, U.S. Census Bureau). The Association of Bay Area Governments projects that the SCC population will increase to over 2.2 million by the year 2030—a 35\% increase.

Despite major population and land use changes since World War II, it was estimated in 2001 that the county was still covered by 35\% forested land, confined mainly to the upper watershed hillslopes (SCBWMI, 2001). According to the U.S. Department of Agriculture (Boryan et al., 2011), forest and woodlands covered $1468 \mathrm{~km}^{2}$ (44\%) of SSC as of 2010 and were confined to upland areas of slope > 10\% (ICF International, 2010). Grazed grasslands covered 31\% and urban development covered another 19\% of the SCC land area.

The continued development of upland forests and woodlands can have important impacts on wildlife habitats throughout the SFBA. Wildlife species at risk in SCC include bobcats, mountain lions, kit fox, badgers, golden eagles, wintering bald eagles, red-tailed hawks, California tiger salamanders, red-legged frogs, and steelhead trout. The Bay Area Critical Linkages Project (BACLP; Penrod et al., 2013) has identified SCC as providing crucial habitat linkages among the southern Santa Cruz Mountains, the Gabilan Range, and the Diablo Range.

The research questions addressed in this study using Landsat satellite image analysis (Cohen \& Goward, 2004) of forest and woodland change in SSC were as follows:

- Where has most forest and woodland habitat been lost in SCC over the past decade?

- What disturbances and land use conversions have displaced most forest and woodland habitat in SCC over the past decade?

\section{Methods}

The Landsat Disturbance Index (DI) was described by Masek et al. (2008) as a transformation of the Landsat (30-meter resolution) Tasseled-Cap data space (Crist \& Cicone, 1984; Huang et al., 2002; Kauth \& Thomas, 1976), specifically designed for sensitivity to perennial shrubland, woodland, and forest cover change. The Tasseled-Cap brightness, greenness, and wetness indices are standard transformations of the original Landsat spectral bands, effectively capturing the three major axes of spectral variation across the solar reflective spectrum. As demonstrated by Healey et al. (2005), the DI is a simple and effective means of tracking vegetation disturbance across ecosystems dominated by woody perennial cover types. Unlike simple visible/near-infrared indices (e.g. the Normalized Difference Vegetation Index-NDVI), the Landsat DI incorporates Tasseled-Cap wetness, thereby including information from the shortwave infrared wavelength, which was shown to be valuable for assessing changes in perennial vegetation structure (Cohen \& Goward, 2004).

The Landsat DI quantifies the normalized spectral distance of any given pixel from a nominal "dense woody vegetation" class to a "bare soil” class. The DI is calculated using the Tasseled-Cap (brightness-greenness-wetness) indices for Landsat images (Kauth \& Thomas, 1976):

$$
D I=B^{\prime}-\left(G^{\prime}+W^{\prime}\right)
$$

where $B^{\prime}, G^{\prime}$, and $W^{\prime}$ represent the Tasseled-Cap brightness, greenness, and wetness indices normalized by a dense woody vegetation index result identified for each Landsat scene. For example:

$$
B^{\prime}=(B-\mu B) / \sigma B
$$


where $\mu B$ is the mean Tasseled-Cap brightness index of the dense woody vegetation class for a particular Landsat scene, and $\sigma B$ is the standard deviation of brightness within the dense woody vegetation class for that same scene. In effect, the DI measures the spectral distance of a given pixel from the dense woody vegetation "centroid" for that scene, in units of within-class standard deviation. Since DI values are based on the statistics of woody vegetation cover reflectance from individual scenes, the DI is relatively insensitive to variability in solar geometry between scenes, and lessens the effect of seasonal vegetation variability among Landsat image dates.

Given the population of mature perennial vegetation pixels identified from recent land cover map products, the mean and standard deviation of each Tasseled-Cap component for the class were calculated. Each TasseledCap image plane was then normalized as in Equations (1) and (2). The difference in DI ( $\Delta \mathrm{DI})$ from July Landsat images was next calculated between 1999 and 2009. Large positive values of $\Delta \mathrm{DI}$ have been shown be associated with a major disturbance event such as wildfire, whereas large negative $\Delta \mathrm{DI}$ values frequently correspond to regrowth of perennial woody vegetation following disturbance (Masek et al., 2008).

Thresholds were next applied to the $\Delta \mathrm{DI}$ values to identify the highest probable areas of ecosystem disturbance or vegetation regrowth/restoration. These $\Delta \mathrm{DI}$ thresholds were determined using wildfire perimeter boundaries mapped on an annual basis by the California Department of Forestry, Fire and Resource Assessment Program (FRAP), with contributions from the USDA Forest Service, the Bureau of Land Management, and the National Park Service (data available at http://frap.cdf.ca.gov/). Manual adjustments of these thresholds were carried out across California to optimize the spatial correspondence between $\Delta \mathrm{DI}$ for areas burned by wildfire before 1999 (regrowth pixels) and those burned between 1999 and 2009 (disturbed pixels).

Forest and non-forest cover was determined from the USDA National Agricultural Statistics Service (NASS) California Cropland Data Layer (CDL) for 2010 (available at http://nassgeodata.gmu.edu/CropScape), a georeferenced land cover data layer with a ground resolution of 30 meters. The CDL was produced using satellite imagery from Landsat and the Indian Remote Sensing RESOURCE-SAT-1 (IRS-P6) Advanced Wide Field Sensor (AWiFS) collected during the local growing season.

\section{Results and Discussion}

Landsat $\Delta$ DI results revealed that $92 \mathrm{~km}^{2}$ (22,730 acres) of forests and woodlands were highly disturbed in SCC between 1999 and 2009 (Table 1). This represented about 6\% of the total $1575 \mathrm{~km}^{2}$ area of all remaining forest and woodlands in SCC prior to 1999, based on the National Land Cover Dataset of 1992 (Vogelmann et al., 2001).

Overlay of FRAP fire boundaries on Landsat results showed that $63 \%\left(58 \mathrm{~km}^{2}\right)$ of the forests and woodlands highly disturbed in SCC had been burned by wildland fires between 1999 and 2009 (Figure 1). The largest forest-rangeland fires in SSC during this time period were the Lick fire of 2007, the Jump fire of 2003, and the Croy fire of 2002. Only 4\% of all burned areas in SCC between 1999 and 2009 showed loss of evergreen forest

Table 1. Landsat disturbed area totals (1999 to 2009) by land cover class within SCC.

\begin{tabular}{|c|c|c|}
\hline Class Name & $\mathrm{km}^{2}$ & Percent Cover \\
\hline Mixed Forest & 27.6 & 29.9 \\
\hline Shrubland & 27.2 & 29.4 \\
\hline Pasture Rangeland & 26.6 & 28.8 \\
\hline Evergreen Forest & 4.2 & 4.6 \\
\hline Grassland Herbaceous & 3.5 & 3.8 \\
\hline Developed/Open Space & 1.7 & 1.9 \\
\hline Open Water & 0.4 & 0.4 \\
\hline Developed/Med Intensity & 0.3 & 0.4 \\
\hline Developed/High Intensity & 0.3 & 0.4 \\
\hline Developed/Low Intensity & 0.3 & 0.3 \\
\hline Woody Wetlands & 0.1 & 0.1 \\
\hline
\end{tabular}




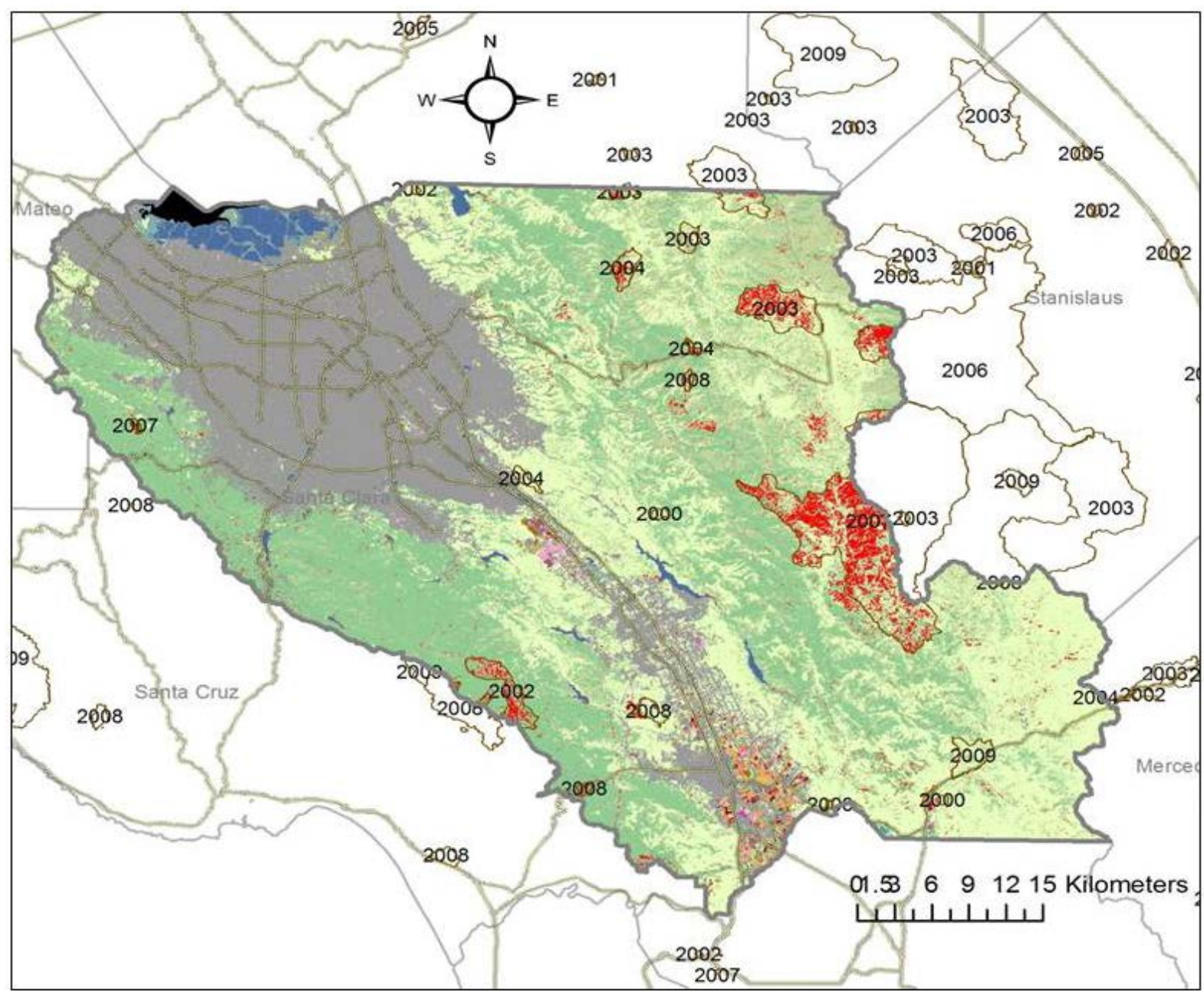

Figure 1. Areas of disturbed forest and woodland cover (in red) in Santa Clara County California from Landsat satellite image analysis between 1999 and 2009. Fire perimeters with dates from FRAP (2010) are overlaid on CDL land cover classes from 2010 (color scheme: green—forest and woodland; tan—grassland; gray-developed and urban; magenta—crop; blue-water).

cover; the vast majority (>93\%) of burned area was instead in mixed forest and shrubland cover. Such fires do not generally result in a permanent conversion for forests and woodlands to a different land use, assuming that the natural processes of vegetation regrowth and succession are not subsequently interrupted by development or agricultural activities such as intensive livestock grazing.

The remaining $37 \%\left(34 \mathrm{~km}^{2}\right)$ of forest and woodland areas that were detected by $\Delta \mathrm{DI}$ analysis as highly disturbed in SCC between 1999 and 2009 did not overlap with any FRAP wildfires boundaries, and hence, were presumably lost to new residential or commercial development activities. It is important to note that the loss of forest and woodland habitat on a unit area $\left(\mathrm{km}^{2}\right)$ basis in these developed areas is equivalent to the disturbance caused by major wildland fires in the region, based on Landsat analysis results. The following areas stood out as the most extensive development areas in the county that resulted in the observable loss of forest and woodland cover since 1999.

Skyline Boulevard and Stevens Canyon Road. A large section of woodland cover was lost to road and housing development in east of Skyline Boulevard, just north of Stevens Canyon Road in the Stevens Creek-Swiss Creek drainages of northwestern SCC (Figure 2(a)).

CA Highway 17 and Summit Road. Large patches of forest cover were lost to residential development along Summit Road in the Santa Cruz Mountains of western SCC (Figure 2(b)). These deforested areas extended along Bear Creek Road, Mount Van Lone, and Patchen Pass. 


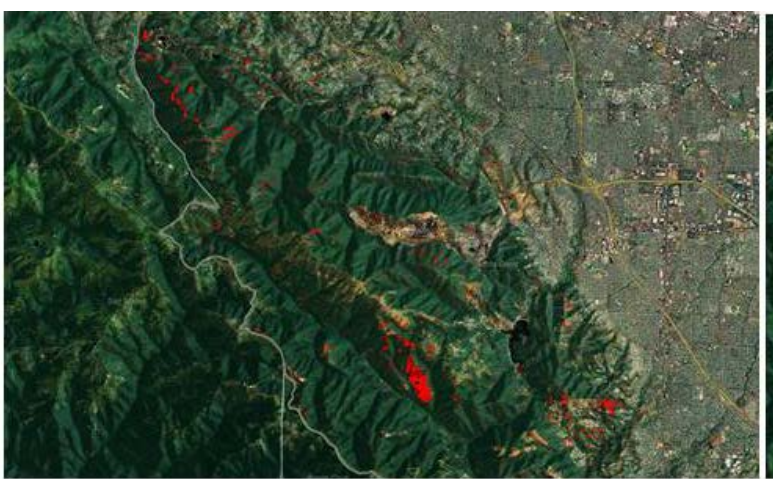

(a)

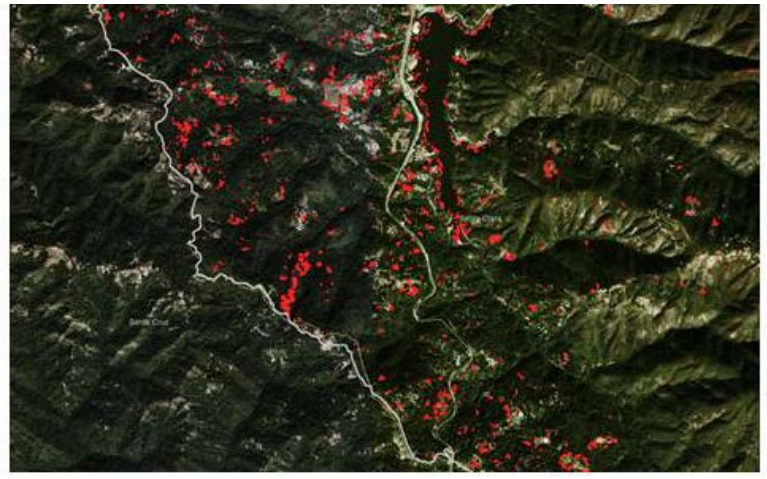

(b)

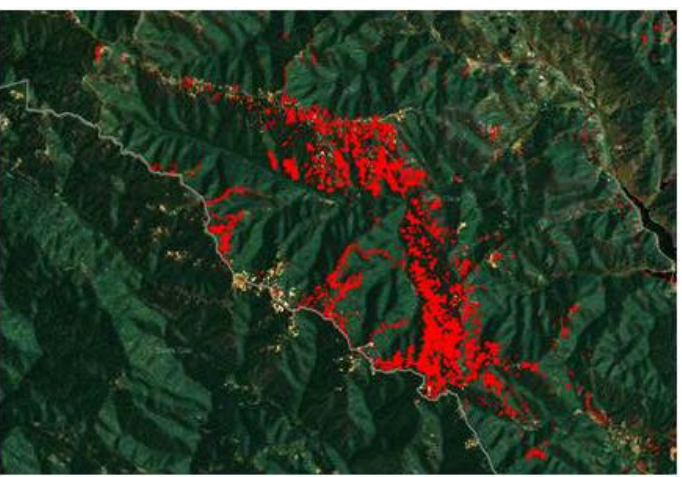

(c)

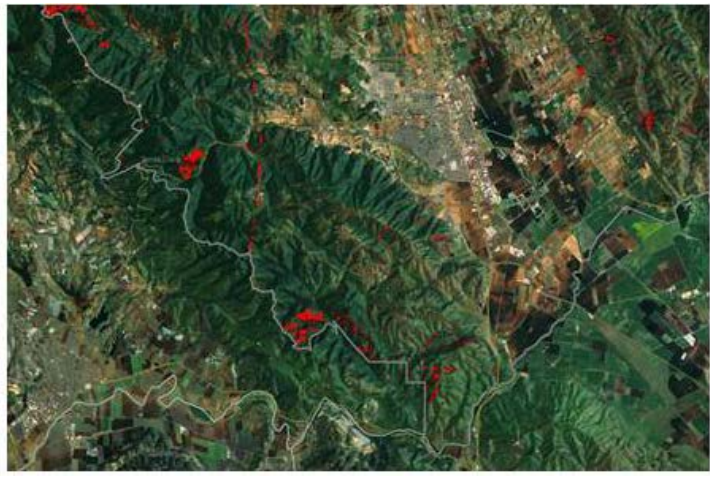

(d)

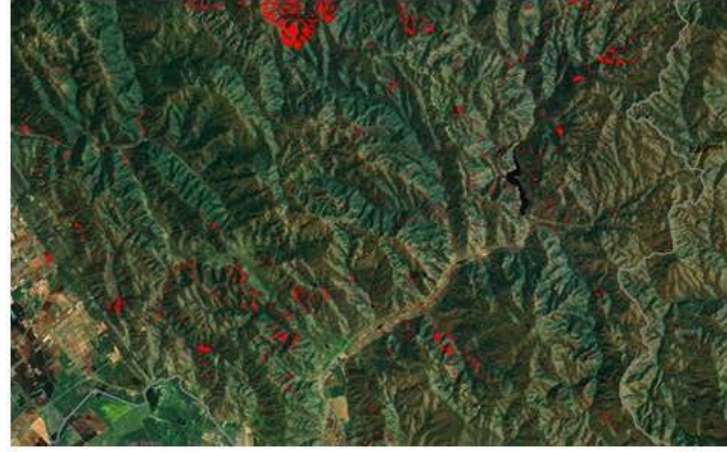

(e)

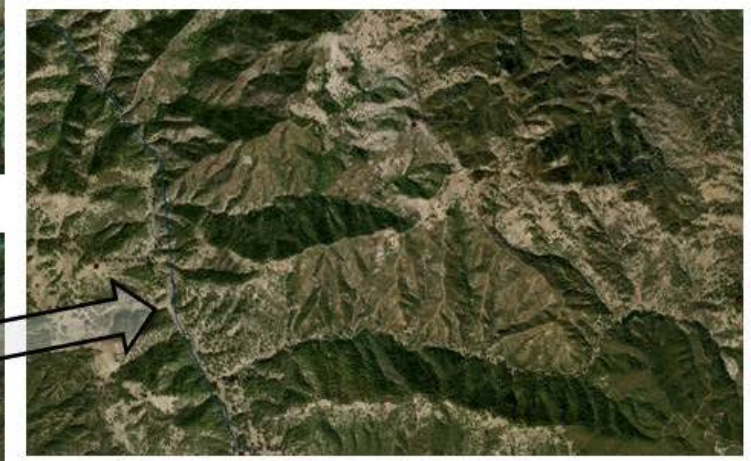

(g)

Figure 2. True color satellite imagery of unburned disturbed forest and woodland cover areas (overlaid in red 30-m pixels) in Santa Clara County California from Landsat satellite image analysis between 1999 and 2009. (a) Skyline Boulevard East; (b) CA Highway 17 to Summit Road; (c) Uvas and Croy Creeks near Morgan Hill; (d) Pajaro Hills near Gilroy; (e) Pacheco Pass Highway; (f) San Felipe hills and San Antonio Valley; (g) Horse Valley. 
Morgan Hill south of Loma Chiquita Road and Little Uvas Road. New roads for development residential housing properties were clearly visible along Uvas and Croy Creeks drainages in southwestern SCC (Figure 2(c)).

Pajaro Hills near Gilroy. Large patches of forest cover were lost to roads for new residential developments in the Star Creek drainage and east of Atherton Peak in the Pajaro Hills of southern SCC (Figure 2(d)).

Pacheco Pass Highway. Road development and grazing activities associated with the loss of woodland cover were visible along both sides of CA 152 not far from the city of Hollister in southeastern SCC (Figure 2(e)).

San Antonio Valley. Large areas of forest cover were lost to roads for new residential developments in the Coyote Creek East Fork headwaters and Grizzly Creek drainage west of San Antonio Valley Road in the Diablo Range of eastern SCC (Figure 2(f)). The most impacted hillsides were bounded by the Stadler Ranch (east), Indian Springs (west) and Lion Canyon (southwest), and also in the Upper Smith Creek drainage above the San Felipe Hills and Horse Valley, west of Pyramid Rock. Disturbed hillsides with dirt roads and sparsely wooded slopes were visible throughout these areas (Figure 2(g)).

According to environmental impact reports for proposed residential developments of existing woodlands near the city of Morgan Hill, CA (CSCDP, 2012), wildlife species that could be adversely impacted by loss of wooded habitats in SCC include the Red-tailed hawk (Buteo jamaicensis), Cooper's hawk (Accipiter cooperii), American kestrel (Falco sparverius), Golden eagle (Aquila chrysaetos)*, San Francisco dusky-footed woodrat (Neotoma fuscipes annectens)*, Mountain lion (Felis concolor), Arboreal salamander (Aneides lugubris), California Tiger Salamander (Ambystoma califoniense)**. Associated loss of wooded wetland and riparian cover to development would further adversely impact the California red-legged frog (Rana draytonii)**, Sierran chorus frog (Pseudacris sierra), Snowy egret (Egretta thula), Great egret (Ardea alba), and Great blue heron (Ardea herodias).

Species labeled with a ** are listed as "threatened" under federal regulations, and those labeled with a * are species of special concern under state regulations. Oak woodland biological communities are generally protected by the State of California under Public Resources Code \$21083.4. If any new development projects would remove at least $2023 \mathrm{~m}^{2}$ ( 0.5 acre) or more of oak woodland canopy, the following mitigation measures must be implemented: 1) planting replacement oak trees and 2) conservation easement establishment.

The Santa Clara Valley Habitat Conservation Plan (HCP) has identified critical regional linkages for wildlife movement in SCC (ICF International, 2010). Wildlife species such as bobcat, mountain lions, black-tailed deer, and American badger (Taxidea taxus)* must move through any newly developed areas of former forest and woodlands while dispersing along the western edge of the Diablo Range. The presence of US Highway 101 and dense urban development in areas of San Jose, Morgan Hill, and Gilroy already act as barriers to dispersal of wildlife species (other than birds and bats) between the Santa Cruz Mountains and the Diablo Range. Forested and wooded uplands of the Pajaro River drainage and the narrow linkage corridor south of the Coyote Valley were included in the BACLP network design to support the needs of species such as California tiger salamander, badger, and mountain lion (Penrod et al., 2013). For most of these focal animal species described in the BACLP, the Parajo Corridor landscape in SCC was identified as providing a crucial wooded habitat connection among the southern Santa Cruz Mountains, the Gabilan Range, and the Diablo Range. Further fragmentation from development of woodlands in corridor zone from the Pacheco Pass to the Parajo Hills will affect wildlife movement in the entire SFBA.

The loss of forest and woodlands in uplands of SCC also adversely impacts crucial ecosystem services, including production of clean water in creeks and streams, soil conservation, aesthetics for tourism, forage for livestock, greenhouse gas emission reductions, and climate stabilization (ICF International, 2010). The locations of forest and woodland loss to recent development reported in this study are mostly on steep hill slopes of SCC, where erosion and disturbance of surface water flows are the most problematic.

Based on Landsat $\Delta$ DI analysis from 1999 to 2009, the current annual rate of forest and woodland disturbance in SCC is $0.6 \%$, which includes areas burned by large wildfires. If most of the disturbed area of forest and woodland in SCC is not allowed to regenerate naturally and remain undeveloped, then this annual rate of disturbance would be equal to annual forest loss rates of countries such as Brazil, Venezuela, Mexico, and Madagascar since the year 2000 (FAO, 2006). Landsat-based analysis with Landsat will continue to provide an objective record of land cover change and loss of forest habitat in SCC on annual basis. Customized Landsat algorithms can be developed to automatically identify and rank the largest contiguous areas of forest and woodland change every year (either re-growth or disturbance) across the SFBA for user-defined buffer zones around critical habitats and wildlife corridors. 


\section{References}

Boryan, C., Yang, Z. W., Mueller, R., \& Craig, M. (2011). Monitoring US Agriculture: The US Department of Agriculture, National Agricultural Statistics Service Cropland Data Layer Program. Geocarto International, 26, 341-358.

Cohen, W. B., \& Goward, S. N. (2004). Landsat’s Role in Ecological Applications of Remote Sensing. BioScience, 54, 535545. http://dx.doi.org/10.1641/0006-3568(2004)054[0535:LRIEAO]2.0.CO;2

County of Santa Clara Department of Planning (CSCDP) (2012). Coyote Highlands Cluster Subdivision Draft Environmental Impact Report, SCH\#: 2012022008. San Jose, CA: County of Santa Clara Department of Planning, 416 p.

Crist, E. P., \& Cicone, R. C. (1984). Application of the Tasseled-Cap Concept to Simulated Thematic Mapper Data. Photogrammetric Engineering and Remote Sensing, 50, 343-352.

Diekmann, L., Algert, S., Gray, L., Hutcheson, J., Scheer, J., \& Sponsler Clements, S. (2013). Santa Clara County Food System Assessment. Sebastopol, CA: Ag Innovations Network.

FAO (2006). Global Forest Resources Assessment 2005: Progress towards Sustainable Forest Management, FAO Forestry Paper 147. Rome: Food and Agriculture Organization of the United Nations.

Forero, L., Huntsinger, L., \& Clawson, W. J. (1992). Land Use Change in Three San Francisco Bay Area Counties: Implications for Ranching at the Urban Fringe. Journal of Soil and Water Conservation, 47, 475-480.

Healey, S. P., Cohen, W. B., Yang, Z. Q., \& Krankina, O. N. (2005). Comparison of Tasseled-Cap-Based Landsat Data Structures for Use in Forest Disturbance Detection. Remote Sensing of Environment, 97, 301-310. http://dx.doi.org/10.1016/j.rse.2005.05.009

Huang, C., Wylie, B., Yang, L., Homer, C., \& Zylstra, G. (2002). Derivation of a Tasseled-Cap Transformation Based on Landsat-7 At-Satellite Reflectance. International Journal of Remote Sensing, 23, 1741-1748.

ICF International (2010). Santa Clara Valley Habitat Conservation Plan. Prepared for County of Santa Clara, City of San Jose, City of Morgan Hill, City of Gilroy, Santa Clara Valley Water District, Santa Clara Valley Transportation Authority.

Kauth, R. J., \& Thomas, G. S. (1976). The Tasselled-Cap-A Graphic Description of the Spectral-Temporal Development of Agricultural Crops as Seen by Landsat. Proceedings, Symposium on Machine Processing of Remotely Sensed Data, Purdue University, West Lafayette, IN, 29 June-1 July 1976, 41-51.

Masek, J. G., Huang, C., Cohen, W., Kutler, J., Hall, F., Wolfe, R. et al. (2008). North American Forest Disturbance Mapped from a Decadal Landsat Record. Remote Sensing of Environment, 112, 2914-2926. http://dx.doi.org/10.1016/j.rse.2008.02.010

Penrod, K., Garding, P. E., Paulman, C., Beier, P., Weiss, S., Schaefer, N., Branciforte, R., \& Gaffney, K. (2013). Critical Linkages: Bay Area \& Beyond. Produced by Science \& Collaboration for Connected Wildlands, Fair Oaks, CA, in Collaboration with the Bay Area Open Space Council’s Conservation Lands Network, 612 p.

Santa Clara Basin Watershed Management Initiative (SCBWMI) (2001). Watershed Characteristics Report, Chapter 4: Land Use in the Santa Clara Basin. Palo Alto, CA: The Santa Clara Basin Watershed Management Initiative, 143 p.

SCCDA (2009). Annual Crop Report. San Jose, CA: Santa Clara County Department of Agriculture, 10 p.

Vogelmann, J. E., Howard, S. M., Yang, L., Larson, C. R., Wylie, B. K., \& Van Driel, J. N. (2001). Completion of the 1990s National Land Cover Data Set for the Conterminous United States. Photogrammetric Engineering and Remote Sensing, 67, 650-662. 